\title{
Surveillance \& Society Images of Suspicion: Article Surveillance Photos in the Brazilian Political Police Archives
}

\section{Mauricio Lissovsky}

School of Communication, Federal University of Rio de Janeiro (ECO/UFRJ), Brazil.

mauricio.lissovsky@eco.ufrj.br

\section{Teresa Bastos}

FAPERJ postdoctoral fellowship at the School of Communication, Federal University of Rio de Janeiro (ECO/UFRJ), Brazil. teresabastos@uol.com.br

\begin{abstract}
Between its foundation under President Vargas in the 1930s until its closure with the end of the Military Dictatorship in 1983, the Brazilian Political Police Archive accumulated more than one hundred thousand photographs, These pictures, now held in the collections of the State Archive of Rio de Janeiro are almost entirely unknown. Despite the big differences between the various governments and regimes during its fifty years of existence, the common objects of surveillance by the police remained remarkably constant: trade unions, political parties, cultural associations, women's movements, student movements, anarchists, communists and terrorists. Foreigners, including diplomats, whose activities raised suspicion of espionage or subversion were also kept a watchful eye on. The contemporary surveillance camera has its signature in the wide-angle plongée machinic abstract style, but in the files of the political police, the watchers are always finding ways to leave traces of their own performances as spies. Agamben's ideas help us to create, in this exploratory article, a dialogic link between the booking photographs taken of the political prisoners and the spy photographs of the usual suspects. In this sense, these images of suspicion testify not only to the "facts" or "feats" of those men and women under observation. In the trail left by these old photographs we can still hear the steps that once choreographed the ballet of surveillance, a strange pas-de-deux that found, in the interstice of the photographic act, a place for authorship.
\end{abstract}

Keywords: Surveillance photography; Political surveillance; Political Police

\section{Introduction}

The state of general surveillance in contemporary societies - which many link to the prevalence of biopower (Foucault 1988) and to the apparatus of the control society (Deleuze 1992) - can be amusing. In Brazil, as the rule of the electronic eye began to gain in strength, humour was generally expressed through the command, "smile, you're being filmed". The command - by means of a popular photographic convention - aims to simulate human interaction in the situation of surveillance; after all, the smile is said to be an attribute exclusive to human beings, available to neither machines nor animals. But, most of all, the command aims to associate an act, a gesture, with electronic surveillance precisely where, a few decades ago, Paul Virilio had signalled its imminent demise (1994).

The requested smile rarely manifests itself, but its mere suggestion induces us to believe that there are still two different categories of people in the world: the watchers and the watched. Therefore, in the apparatus

Lissovsky, Mauricio and Bastos, Teresa. 2012. Images of Suspicion: Surveillance Photos in the Brazilian Political Police Archives. Surveillance \& Society 10(1): 65-82.

http://www.surveillance-and-society.org | ISSN: 1477-7487

(C) The author(s), 2012 | Licensed to the Surveillance Studies Network under a Creative Commons

Attribution Non-Commercial No Derivatives license. 
of electronic surveillance there still remains something of that specific interpersonal relationship where humanity shows itself through a slight curling of the lips. Even if the smile never surfaces on the face, we cling to its idea, as if we might once more find the remnants of individuation that constitute us as subjects: watchers and watched, among other things (Foucault 1977).

However, if we can or cannot smile while facing this command, it is impossible for us to not not smile (that is, to barely contain a smile), to not not avoid laughing (sardonically), or, simply, like Bartleby, to be able not to be able to smile. That which at first glance seems to us like a choice - to smile or not to smile ends up revealing us as beings who are doubly impotent, that is, beings who are incapable of their own impotence (Agamben 2007: 34-6). Beings whose gestures were kidnapped and now occur to us in another territory, far away from that one where our subjectification used to take place (Agamben 2005a).

In front of the electronic eye of contemporary surveillance, every smile is embarrassed. And every lack of smile represents a submission to the demand to "act normally" conforming to something that became indeterminate and vague, but that surely occurs when "to smile" or "not to smile" is no longer the question.

The non-electronic images that we discuss in this article are of a different kind. They belong to the archives of the Brazilian political police (usually known as DOPS - Department of Political and Social Order), a collection of images that grew unceasingly from the time of its creation in the 1930s during the Vargas Era until its dissolution with the end of the military regime in the 1980s. The photographs are of undercover surveillance, crime scenes, images apprehended after the arrest of suspects and the discovery of hideouts of underground organisations. Amongst the various categories of photographs held in these archives, the most common is the booking photograph or mug shot. ${ }^{1}$

In the studios where these photographs were taken - which were frequently the antechamber to torture and imprisonment - there was never a sign commanding, "Smile, you're being booked". Nonetheless, in front of that apparatus which demanded the "neutral", the "zero degree of expression", (Lissovsky 1993) a smile would sometimes seep in. There, where no further gesture seems possible, where the possibilities of action are exhausted, the face is all there is left (Photographs 1 and 2).

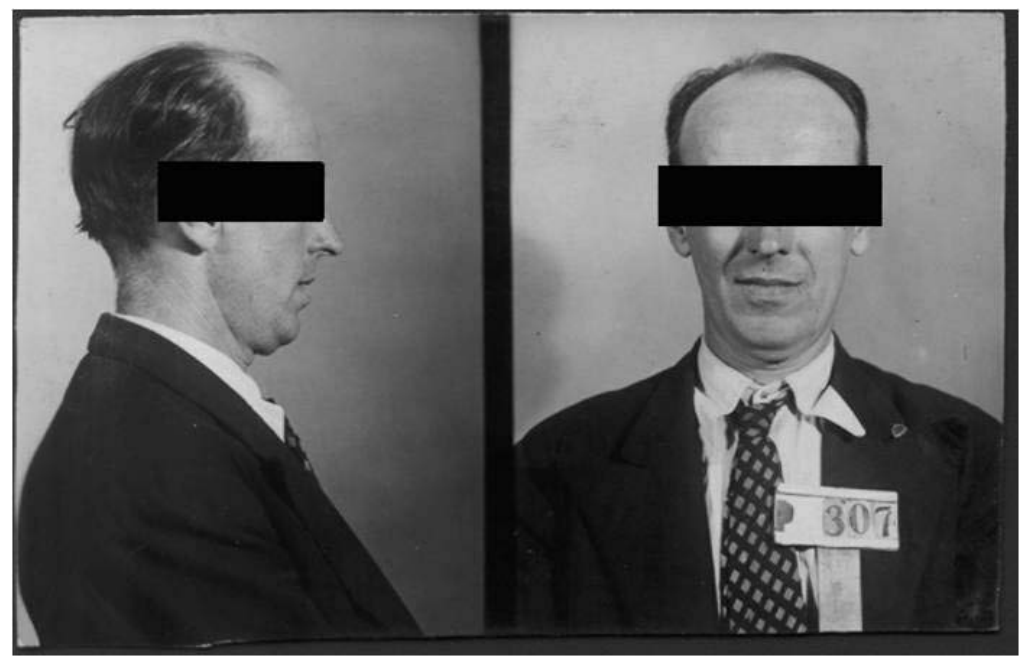

Photograph 1

Booking photograph for the Brazilian political police from the Estado Novo period (1937-1945). The identification of the subject is protected in accordance with Brazilian law (APERJ Photographic Collection).

\footnotetext{
${ }^{1}$ They are linked to the files of about 52,000 suspects.
} 


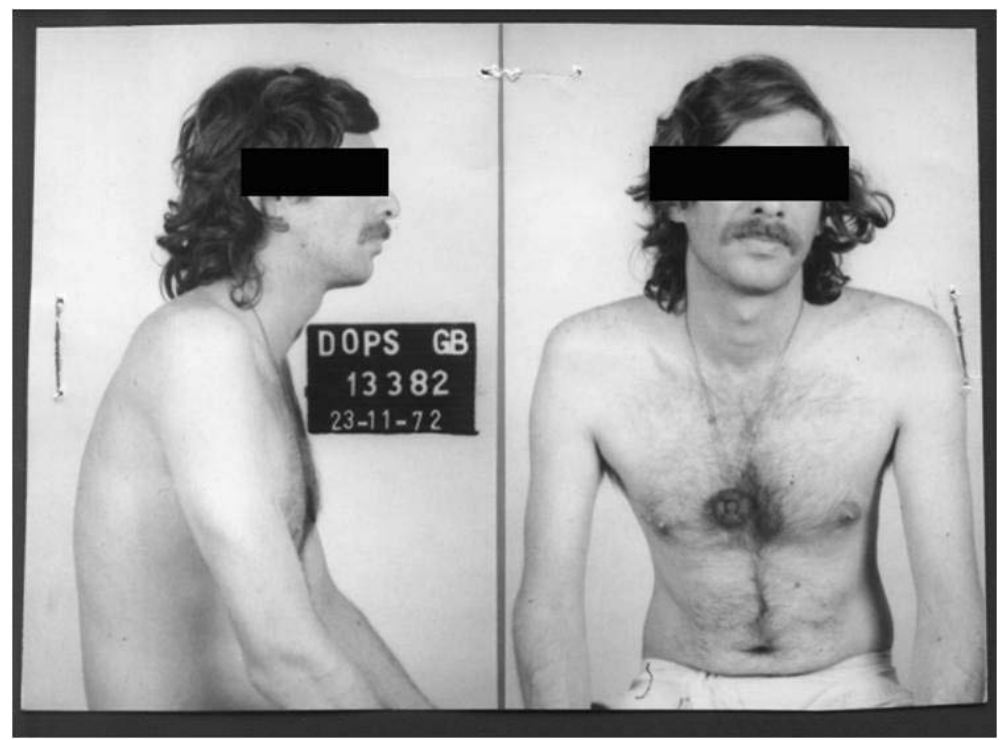

Photograph 2

Booking photograph for the Brazilian political police from the period of Military Dictatorship (1964-1985). The identification of the subject is protected in accordance with Brazilian law (APERJ Photographic Collection).

The imagined receiver of these facial expressions remains uncertain. In that very instant, perhaps pressured by time, these "infamous" men and women (Foucault 2003) had no time to decide who they were posing for. But it is not inconceivable that some of these smiles - and also the expressions of sadness, fatigue, superiority, firmness or supplication - were aimed at the gaze of the "watcher". Prompted by the question that these faces pose, we also confront this other gaze like the prisoner who tries to see his or her destiny in the face of the executioner. When we explore these images, however, we do it from the reserve of meaning that the smile opens up to us, as one that introduces, in the most monolithic of texts, the frail detour of a parenthesis.

\section{Photography in the archives of the political police of Rio de Janeiro}

Between 1922 and 1983 the "political" and "social" surveillance of citizens was carried out by a succession of public agencies and police units. They would produce, store and manipulate data, expanding or restricting the extension of their activities in accordance with the interests of the administration they served. Even before the formal establishment of a political police organ in the 1930s, there had existed various corps of agents or sections in the Civil Police of Rio de Janeiro in charge of political repression. For example, during the aristocratic Old Republic, which lasted from 1907 to 1930, the capital's "Social Order Section", 2 which was in charge of the surveillance and repression of political street conflicts, was commonly known as the "secret police". But it was in the 1930s, during the Getúlio Vargas dictatorship, that their powers were increased significantly. Within the newly created Special Precinct of Political and Social Security (DESPS), whose agents were known by the feared term of 'special police', photographs began to be systematically produced and stored by the agency, with particularly thorough documentation of the participants and ruins of an attempted communist revolt in Rio de Janeiro and Natal in 1935.

After the fall of the Vargas Dictatorship in 1945, the political police remained faithful to their goals of intelligence and surveillance, but did not regain their former "prestige" until the start of a new dictatorship, following the military coup of 1964. By this point, the agency was already called DOPS - the Department of Political and Social Order - an infamous acronym by which the civil political police would be known throughout the military dictatorship.

\footnotetext{
${ }^{2}$ Rio de Janeiro was capital of Brazil until 1960 when political power was transferred to the newly constructed Brasilia.
} 
After re-democratisation in 1983, the Department was finally closed down. Only then, after 70 years of uninterrupted activities, did the function of political and social repression disappear from the administrative structure of Rio de Janeiro. ${ }^{3}$ During those seven decades, despite evident differences between the civil dictatorship of Vargas and the later military dictatorships, and between the authoritarian and democratic regimes, there was a striking constancy in the subjects of surveillance. These included a range of labour unions, political parties, cultural and charitable associations, the women's movement, the student movement, anarchists, integralists (Brazilian fascists), communists, military men and terrorists. In addition, foreigners suspected of espionage or subversion, including diplomats, were also the subject of surveillance activities.

The relative continuity within the administration of the political and social surveillance agencies that substituted one another during this period allowed for the growing specialisation of the members of the political police, even during the democratic interregnum. The corollary to this, within the context of the military dictatorship, was the formation of the so-called "information community", which was composed of cooperating civilian and military agencies. Since Rio de Janeiro was the site of greatest political and cultural importance in Brazil until the transfer of the capital to Brasilia in 1960, it was both the commonly chosen location for expressions of militancy by students, intellectuals and labour unions and, for that very same reason, the object of obsessive (and frequently implacable) activity on the part of the Brazilian political police. In that sense, the operational structure and the modus operandi of Rio de Janeiro's agents frequently became a model for the rest of the country. Due to its strategic position, Rio de Janeiro also held records gathered in other states of the federation, and its agents collaborated in the prevention and suppression of subversive activity elsewhere in Brazil.

The main reason for this operational continuity was the fear of communists, who, throughout the existence of the agency, were considered the main enemies of the state. In large part the history of the police and the history of the Brazilian Communist Party coincide. Both were created in 1922 and the actions and structures developed by the police were frequently a direct response to the demands of surveying and thwarting the "reds" as they were generally known.

In an interview, former agent Cecil Borer" stated that "during the 1940s and 1950s, we did not worry about the activities of Ademar de Barros' party (the Labour Party), but the Communist Party was a terror, was extremely harmful. In the Brazilian Communist Party there was no political conduct, rather there was subversive conduct" (A Contradita 2000: 37). The interview with Borer, who in 1963 rose to become director of DOPS, is exemplary in showing the links between the two organisations: "I had the key to the door of the Party's Central Committee. We would go there, open it, search everything, take photographs, and take everything out. We removed documents from the binders and put them in our files" (38). This continuous production and apprehension of documents - with the frequent discovery of "hideouts" allowed the police to amass a gigantic quantity of documents; 750 linear meters of textual records and a collection of photographs still not entirely catalogued but estimated to contain one hundred thousand images in the form of copies, glass negatives and acetate negatives.

For several decades, the photographic evidence was collected by a section of the police known as the "Technical Section", responsible both for the production of booking photographs and for surveillance and espionage images captured on the streets or at sites of political and social demonstrations. In spite of the

\footnotetext{
${ }^{3}$ In 1992 the records acquired by DOPS and its predecessors were placed in the holdings of the Public Archives of the State of Rio de Janeiro (APERJ). This collection - the largest of its type in Brazil - is particularly important, since the files of the military agencies of political repression have never been opened to researchers and it is impossible even to firmly state that they are still in existence.

${ }^{4}$ Cecil Borer enrolled in the Vargas Special Police in 1932 at the age of 18 , and he rose to become chief of the Labour and the Investigations Sectors. He finished his career as director of the DOPS from 1963 to 1965. His interview is extremely valuable in understanding the operational proceedings of the agency.
} 
many changes to its name and position within the organisational structure of the police, it is noticeable that there was always a section responsible for photographic activity. In the internal correspondence that records requests for consumer goods, orders for cameras and flashes are frequent.

An examination of the documents, which are rarely signed, leads us to suppose that the agents who went out on the streets to perform activities of surveillance and espionage, at least when it came to producing photographs, were not usually directly responsible for filing the images. This discontinuity between image producers and information analysts highlights, we believe, a marked preference for infiltration techniques by the Brazilian political police. In addition to infiltration of newsrooms, in many cases there was an actual collaboration between the police and the press, which resulted in a frequent exchange of photographs. The obvious reason for this approach is that journalists have an implicit free pass to "photograph" and "interrogate" anyone, anywhere, without raising suspicion.

According to Cecil Borer, "in infiltration, you act in accordance with either the English or the American technique. The English technique involves creating the agent, and I did that a lot". According to this model, a given individual was chosen by the police officers, who would secure employment for him in an appropriate company. In the case of infiltration of leftist organisations (the main object of interest and concern of the political police throughout its existence), the chosen person first received a basic "leftist" induction before beginning to attend the union, association or entity he or she was desired to spy on. As soon as this person was absorbed by the organisation, he or she began to produce information. The American system, according to Cecil Borer, was to "buy" the agent. That is, after identifying somebody who held a position of interest he or she would be harassed in "several ways": "you offer them a few favours, a friendly relationship and, after a while, using the dollar, he would become a source of information". Borer states that he "had few agents who were bought, because the funding was almost insignificant". In spite of the fact that the government was a dictatorship and, "therefore, based on information", there were no financial resources made available for "forming a highly paid intelligence network" (A Contradita 2000: 25).

The regard of the "infiltrated" has its peculiarities. If the camera of contemporary surveillance found its distinctive mark in the use of wide-angle lenses and high angle shots, constituting a machinic statement without enunciation (the statement of a universal surveillance), the photographer-spy-journalist-comrade of the political police rarely neglects to show in the images the circumstances and conditions of its production. In that sense, they are witnesses not only to the watched but also to the watchers, leaving traces of an enunciation of the surveillance that photography retains like the crystallised figure of a strange pas-de-deux.

In this article we examine three series of political surveillance images: the first, from 1959 (therefore, from before the military dictatorship), relates to a stay in Rio de Janeiro made by a Soviet scientific ship; the second, from 1967, originating from the first phase of the dictatorship (prior to the greater hardening of the regime), registers a Carnival ball promoted by notorious left-wing intellectuals; the third, from 1977, the beginning of the so-called "political opening", records the movements of a union activist. What we aim to uncover in these images, beyond the duel of furtive looks, evasions and dissimulations, are the ways through which, within the photographic act, watchers and watched reciprocally constitute one another. ${ }^{5}$

\footnotetext{
5 Among the thousands of images making up the collection, these three groups of photographs were chosen for two reasons besides their chronological distribution. Firstly, they form series of images taken at specific events, and are therefore potentially more susceptible to an analysis of procedure and, we initially supposed, more relevant than the majority of series which are composed of odd photographs. Secondly, from the formal point of view, they present contrasting but representative examples of the patterns of surveillance photography found in the archives. What we would like to highlight here, therefore, is that the constitution of the corpus of our analysis stems directly from the images, not from the documents associated with them.
} 


\section{9 - Soviet Scientists visit Corcovado}

An interesting example of the production of surveillance images during the democratic period prior to the 1964 military coup is occasioned by the visit to Rio de Janeiro of the Soviet oceanographic ship Mikhail Lomonosov. From 1-6 June 1959, the crew of the ship were under the watchful eyes of the Police, as Jair Leão Mendes, chief of SAE (Section of Foreign Activities) revealed in a memo from 8 June 1959:

Honourable Director of the DPS, In accordance with your verbal instructions, this Section boarded the Russian ship Mikhail Lomonosov, which arrived in the capital on the first day of the current month. As is generally known, the aforementioned ship, which is used for oceanographic research commissioned by the Moscow Academy of Science, brought 65 scientists (1 Polish, 4 German and the remaining Russian), from a total of 132 crew members who, according to their statements, work in the Russian Program of Cooperation for the International Year of Geophysics, which has already come to an end but which still allows them a little bit of work. (...)

Still in accordance with your instructions, this Section has identified 128 of the crewmembers, with the remaining four denying our request.

Given that the above-mentioned ship remained here for 6 days, this Section performed the necessary surveillance, for the crew had permission to disembark in order to see the city, permission which was given by His Excellency, the President of the Republic.

Therefore, on the $3^{\text {rd }}, 4^{\text {th }}$ and $5^{\text {th }}$, with their respective identification cards, they went to the picturesque sights of this capital (APERJ: 43,28$){ }^{6}$

The photographs register the trips of the scientists and other crew members to Copacabana, to the statue of Christ the Redeemer, to the Museum of Hunting and Fishing in Quinta da Boa Vista, and to several other locations in the city which were not specified in the archives (Photographs 3 to 7). Today, it is difficult to determine the nature of the relationship between the watcher and the watched of which these photographs serve as proof. The police photographer did not hide. On the contrary, he took part in the trips as one among many "tourists" that, with their cameras, gathered souvenirs for their family and friends. In Photograph 3, looking for the shelter of a parasol, he is just one more person to photograph the trip to the beach at Copacabana; in photograph 5 he sits at the table drinking the Brazilian carbonated beverage guaraná with the younger members of the group.

There are no apparent restrictions on the work of the police photographer and neither do the watched seem to alter their behaviour due to the presence of the watcher. Compared to the whole DOPS collection of photographs, the images related to this mission present a rare concern with aesthetic and expressive values. In this sense, a curious correlation can be established between the photographs and the report that accompanies them, signed by the chief of the Section of Foreign Activity. While the latter uses his scanty stylistic resources to cast suspicions over the true interest of the ship's crew ("...according to their statements, work in the Russian Program of Cooperation for the International Year of Geophysics, which has already ended..."), the photographer makes the best of the opportunities he has to transform his mission into a social news story with tinges of irony. Thus, the Russian cameraman is photographed in a monumental low-angle shot, so characteristic of Soviet iconography of the time, but with the statue of Christ the Redeemer in the background (Photograph 4). A similar expressive expedient can be observed in Photograph 6, where the police photographer moves to the other side of the counter - to the place of "the Portuguese man", that is, the owner of the bar - and foregrounds the icons of Yankee imperialism, the bottles of Coca-Cola that the Soviets were drinking. So too he captures the intrigued expression of one of

6 The passports of the passengers and crew were photographed by the police, and the reproductions are part of the image collection of APERJ. 
the visitors as he peers at a jar of lupin seeds, so characteristic of the bars of Rio at that time (Photograph $6)$.

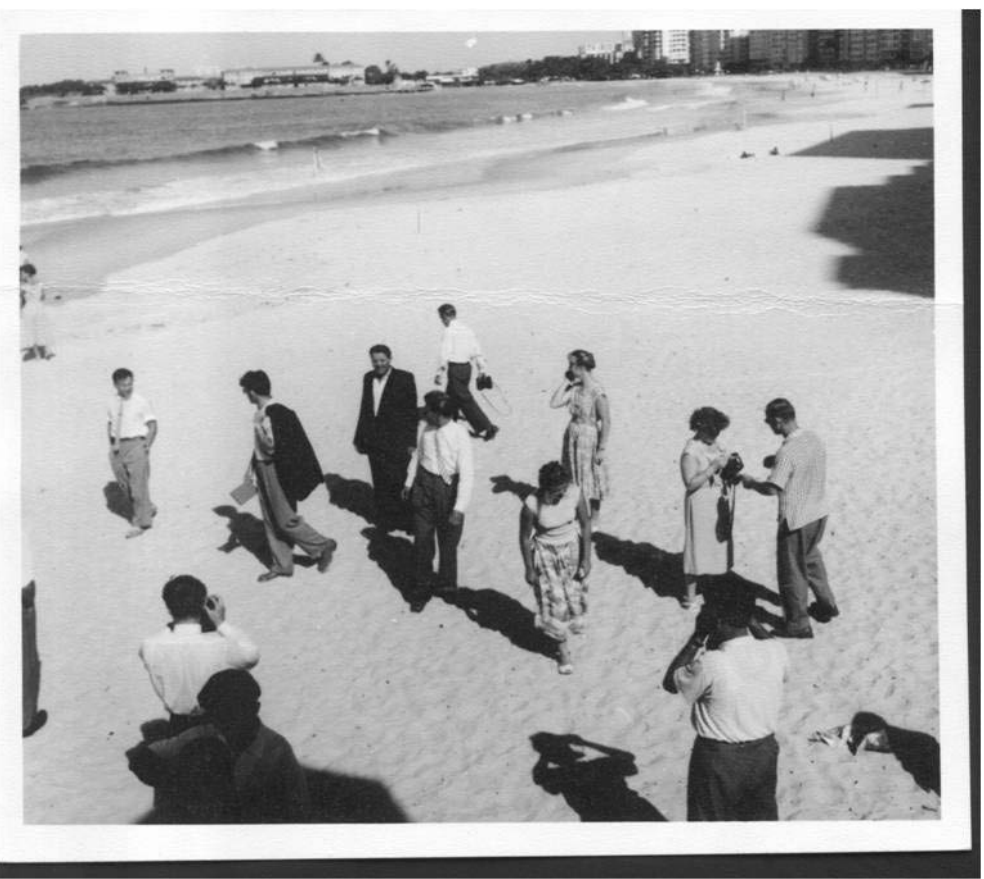

Photograph 3

Scientists of the Soviet oceanographic ship Mikhail Lomonosov visit Copacabana Beach, June 1959. The police photographer is one among many other photographers. APERJ Photographic Collection.

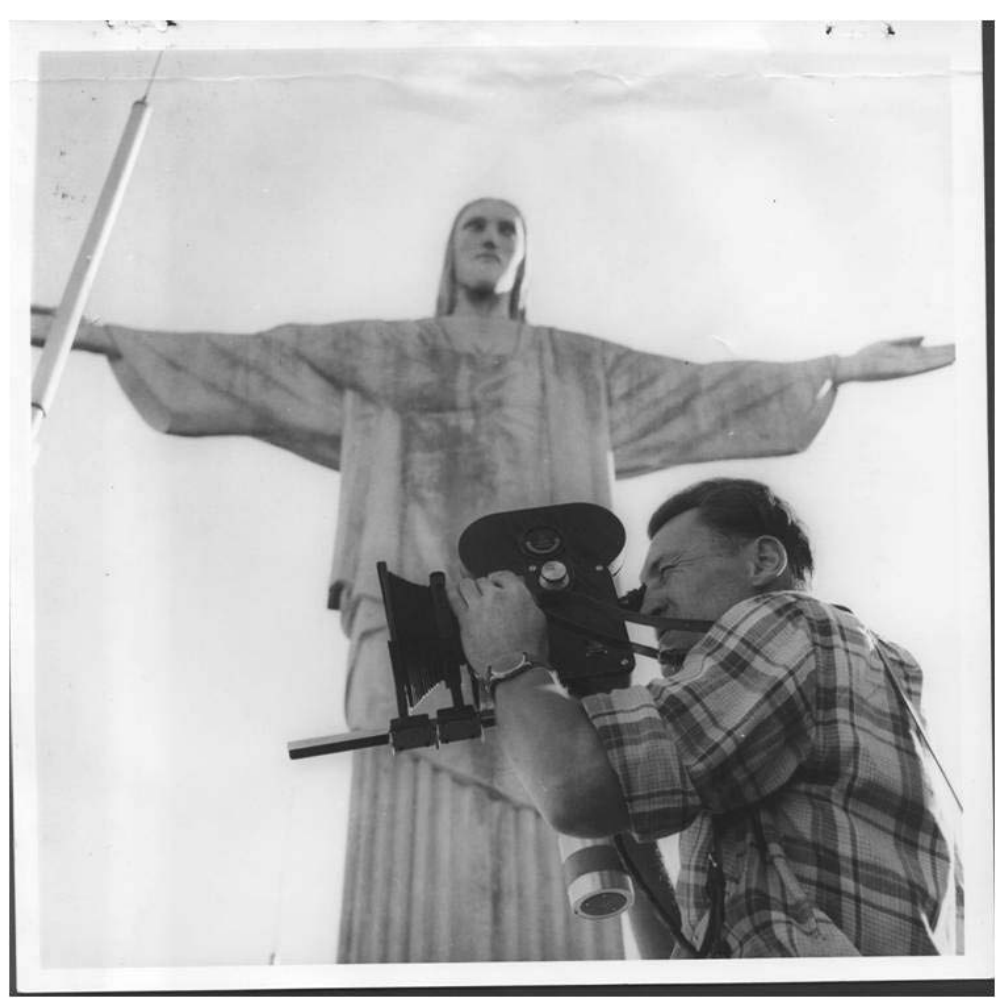

Photograph 4

Monumentalist shot of the cameraman of the Soviet oceanographic ship Mikhail Lomonosov on Corcovado Mountain, June 1959. APERJ Photographic Collection. 


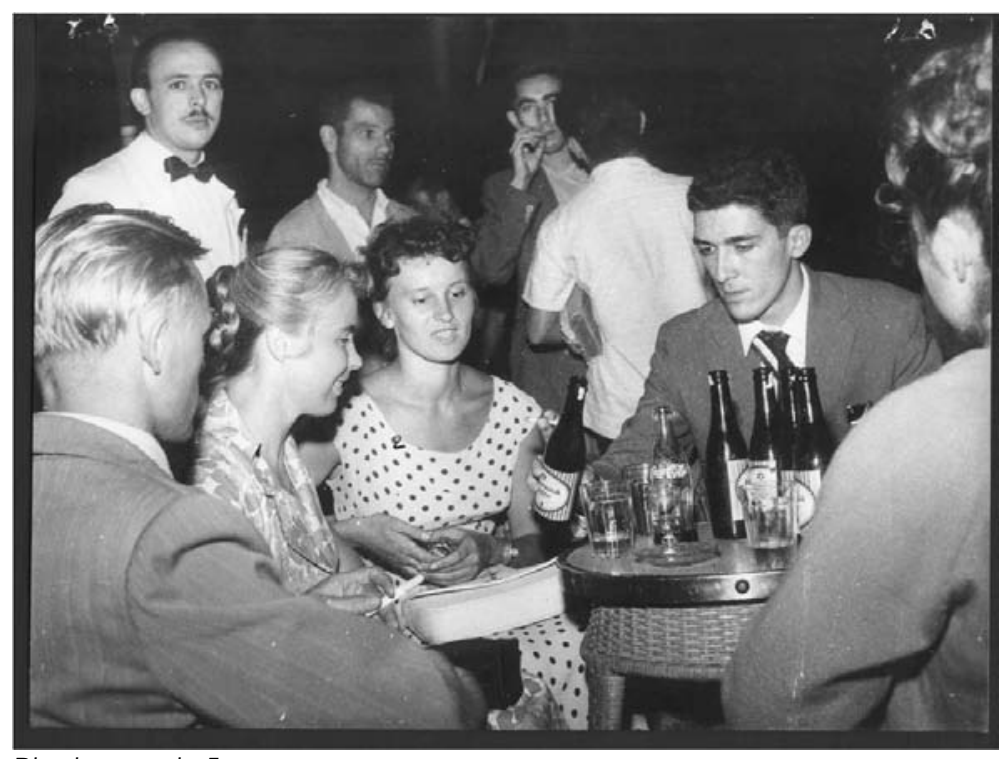

Photograph 5

Crew of the Soviet oceanographic ship Mikhail Lomonosov drink guaraná in the Rio evening, June 1959. APERJ Photographic Collection

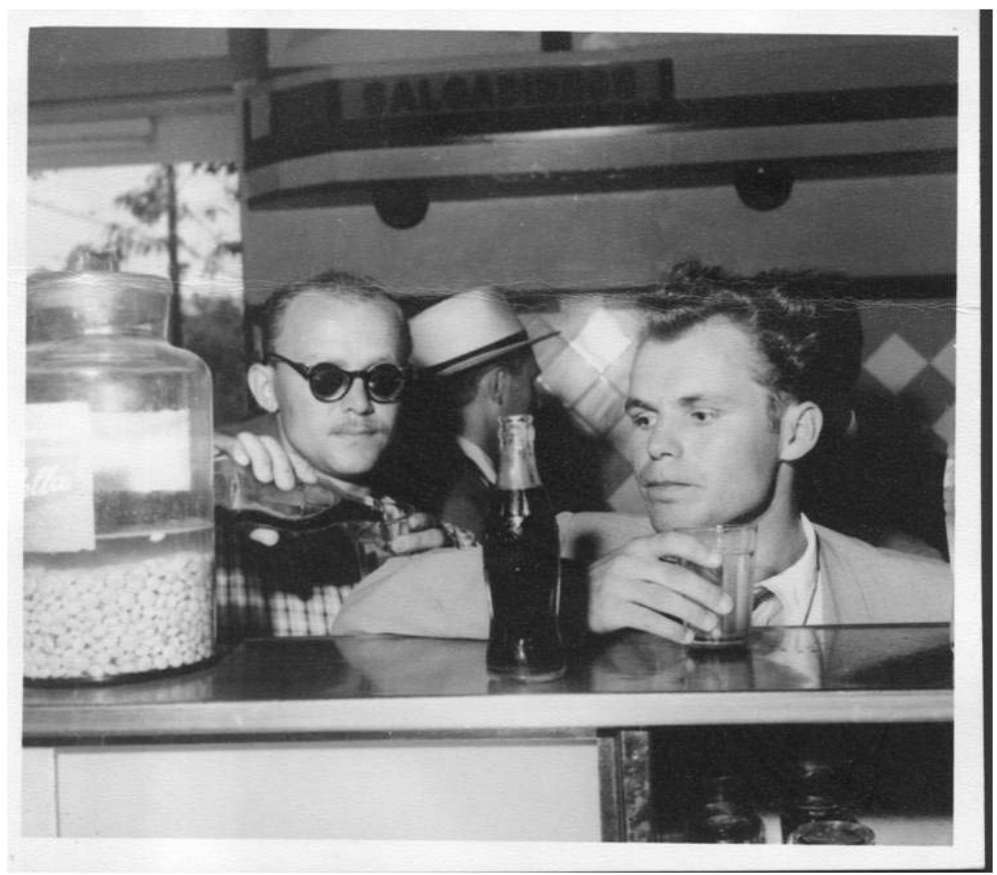

Photograph 6

Soviet scientists in a typical Rio bar, June 1959. The police photographer jumped to the other side the counter. APERJ Photographic Collection. 


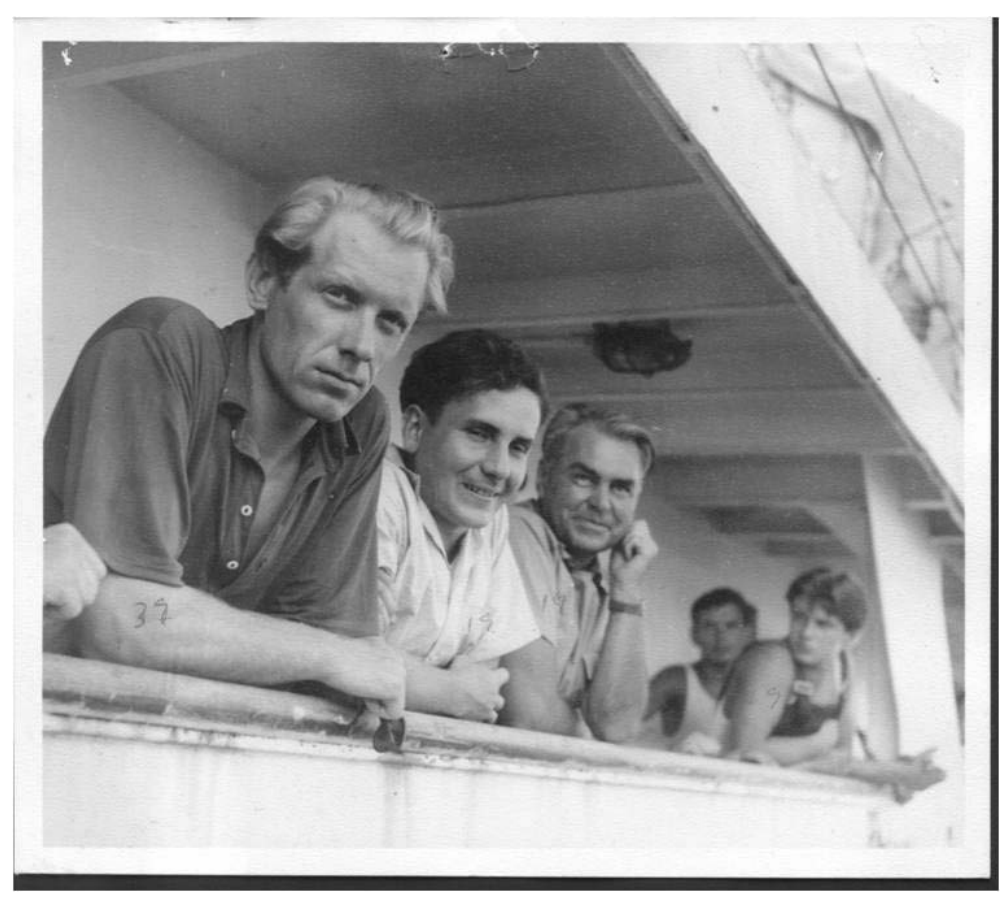

Photograph 7

Aboard the Mikhail Lomonosov. The Soviets pose for the police photographer, June 1959. APERJ Photographic Collection.

After three days of excursions, the members of the scientific expedition of the Soviet oceanographic ship Mikhail Lomonosov observed the port from on board the ship. As in several other images of this series, they pose for the police photographer. Some even smile for the man that "accompanied" them on their tour of Rio, as they did for the cameras of their fellow passengers. But, if we examine these photographs closely, we can see the marks of surveillance that are superimposed over the gesture of the "reportertourist". They are the little handwritten numbers which are visible in several of these images, such as in Photograph 7, for example. They correlate the actions of the watched to their identification files, generated from photocopies of their passports. These joyful souvenirs of a visit of "highly suspicious" Russian scientists to the "Marvellous City" would hardly find their place in the files of the political police without these marks imposing their logic and their destiny upon them. This secondary work on the images must be the reason why the copies of the passports took over a month to be forwarded from the identification section to the appropriate files. Therefore, on July 8 1959, a month after ship has departed for Riga, the city from where it had originated, the Chief of the Technical Section sent them over to the Chief Inspector of the Section of Files and Registries, with the following memo: "Along with these, I forward to you 128 photographs of passengers of a Russian ship (Mikhail Lomonosov), which was in our port. The necessary explanations can be given by the Section of Foreign Activities" (APERJ: 43, 32). As far as we know, such explanations were never requested, whether they were necessary or not.

\section{7 - The "Ball of the Festive Left"}

It is natural that the surveillance activities of the political police intensified after the military coup of 1964. Among the dozens of rallies and notoriously political events that were watched and photographed by the police of Rio de Janeiro, one distinguishes itself from the others. It is a Carnival ball that took place on February 2 1967, at the Café-Concerto Casa Grande, in Leblon, a rich ocean-fronting neighbourhood in the south zone of the city. The episode is particularly interesting because it allows us to describe the main instrument of internal circulation of information gathered through surveillance within DOPS during the military dictatorship, the "reserved bulletin". 
These "bulletins", which were written weekly, possessed their own sequential numbering system, and their distribution was restricted to the units that integrated the internal staff of the Police. They were directed to the respective chiefs who were responsible for the control and revelation of the materials contained within, according to the degree of secrecy that was imposed. On the cover of the bulletins was the badge of the Secretary of Public Security, and immediately under it, the words "Department of Political and Social Order', with a grade indicating the degree of secrecy which should be applied. The layout followed a set pattern - with a $20 \times 30 \mathrm{~cm}$ format - and the first page contained a table of contents that ordered the main news items of the week according to importance. The degree of importance of the material corresponded to the level of threat that they were perceived to represent to the social order. The list included both events that had already occurred and those that would still come to pass. The bulletins do not contain any signatures, much less the attribution of responsibility for the data to any particular agency.

In Reserved Bulletin No. 7, from February 1 1967, the second entry was entitled: "Communism - Ball of the 'Festive Left"'. On a subsequent page, information linked to this heading was as follows: "Tomorrow, on the $2^{\text {nd }}$, at 10 p.m., at the Casa Grande, in Afrânio de Melo Franco Street, there will be a Carnival ball sponsored by the intellectuals of the "Festive Left"'. The text, although concise, was sufficient to trigger the machinery of surveillance and mobilise the necessary teams. In that sense, they remind us of the kinds of reports which in newsrooms are called "subjects of the day". It is through these that journalists and photographers receive details of the stories they need to research.

The level of relevance and the corresponding threat of the above mentioned ball - presumed from its position in the table of contents - was corroborated in the richly detailed narratives produced by the agents for inclusion in the Reserved Bulletin of the following week. This level of threat is also evidenced by the production of dozens of photographs of the event. In spite of the fact that the photographs are not mentioned in the bulletin, their material characteristics indicate that they were produced by agents of the police itself: $13 \times 18 \mathrm{~cm}$ format, images slightly washed out on the amplifications, straight margins and the same type of paper generally used by police laboratories. Photographs 8, 9 and 10, presented below, are from among those taken by DOPS agents at the Ball of the Festive Left (also called "Fe.Be.A.Pa. Ball", by its promoters), during Carnival, 1967. ${ }^{7}$

In these images, the photographer, who at first behaves like any other guest, taking his pictures discreetly from one of the tables at the back of the room (Photograph 8), then begins to proceed more and more obviously (Photographs 9 and 10). The hand that covers the face (Photograph 9) is a response to the watchful performance that the agent demonstrates not only for his superiors but for the watched themselves - a performance exacerbated by the use of the flash. Reserved Bulletin No. 8 of February 10 1967 describes in detail the place and the atmosphere of the party:

On the $2^{\text {nd }}$ of this month, in the ballrooms of the 'Café concerto Casa Grande', no. 300 Afrânio de Melo Franco Street, Leblon, the Carnival ball sponsored and organised by intellectual members of the "Festive Left" took place, in accordance with what D.O.P.S. had anticipated in R.B. no 7 (...) The ball was called 'Fe.Be.A.Pa' - which means - as we found out - "festival of stupidities that devastate the country' (...)

\footnotetext{
${ }^{7}$ Fe.Be.A.Pa, the "Festival of Stupidities that Devastate the Country" was a notorious trademark of the humorist writer Sérgio Porto - a.k.a. Stanislaw Ponte Preta - who used it to ridicule acts and speeches of the politicians, and was published in the newspaper Última Hora.
} 


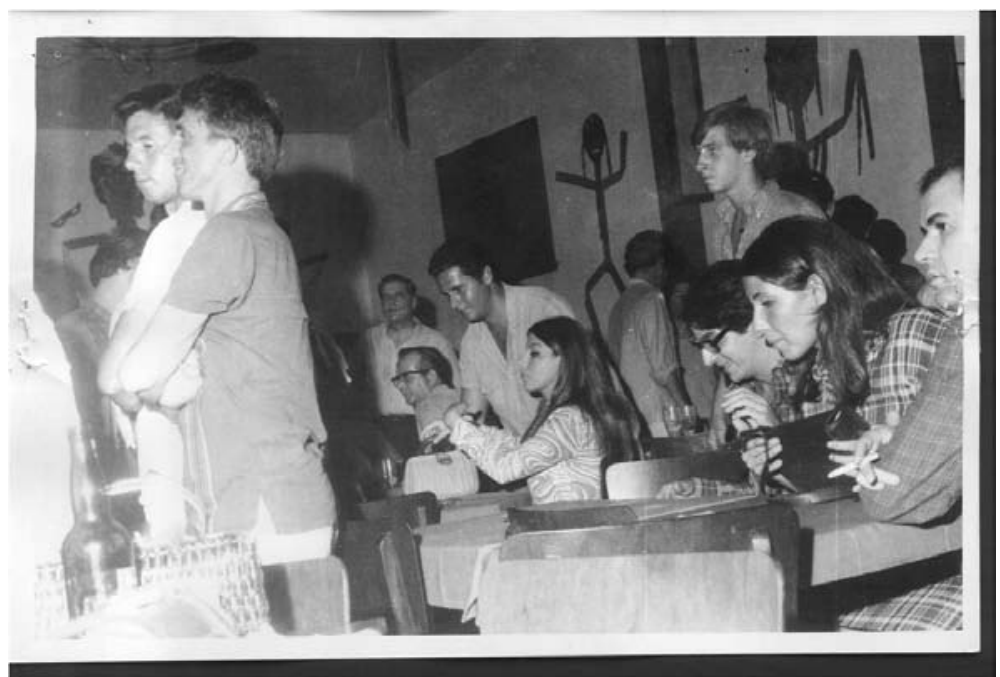

Photograph 8

Fe.Be.A.Pa. Ball, Café-Concerto Casa Grande 2/2/1967. The DOPS photographer is sitting at the table among the "festive leftists". APERJ Photographic Collection.

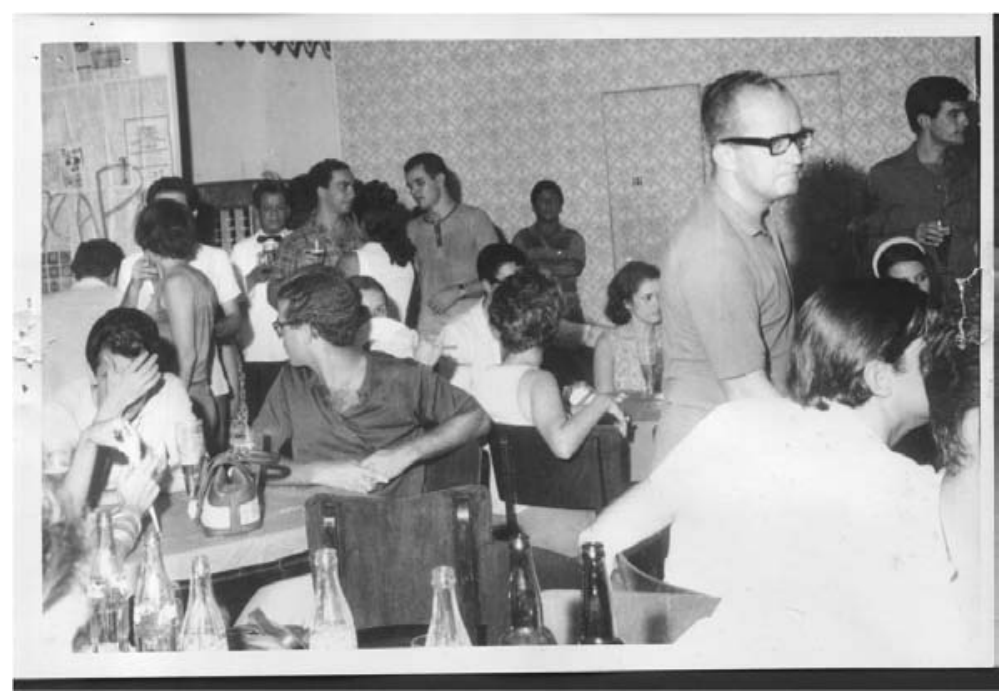

Photograph 9

Fe.Be.A.Pa. Ball, Café-Concerto Casa Grande 2/2/1967. Already on his feet, the DOPS photographer does not seem at all concerned with hiding his goal of photographing those present. A few revellers hide their faces. APERJ Photographic Collection. 


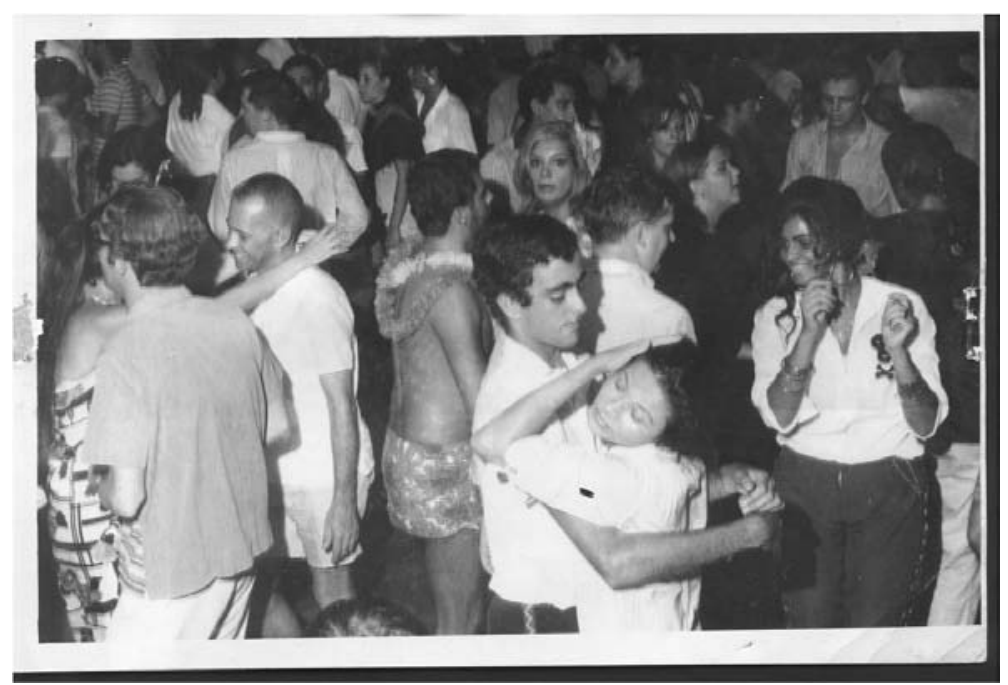

Photograph 10

Fe.Be.A.Pa. Ball, Café-Concerto Casa Grande 2/2/1967. Increasingly enthusiastic, the photographer gets up on the table to have a privileged view of the room. APERJ Photographic Collection.

According to the report, a large part of the walls of the ballroom were "decorated" with the political sections from the newspapers (which can be partially observed in Photograph 9). The report also states that:

During the ball, the Carnival march 'Máscara Negra' [Black Mask] was sung countless times with the lyrics changed to contain words offensive to the person of the president of the Republic and several other personalities of the country, and also alluding to the current national policy and to Marshall Costa e Silva. ${ }^{8}$

The Bulletin cites the names of some of the intellectuals and artists present and, as might be expected, it concludes by pointing to the necessity of following up on future related events:

According to data collected at the venue, intellectuals, artists, journalists and students gather on Mondays at the 'Café-concerto Casa Grande'. We discovered also that uncensored art films will be screened for the same type of audience at the cinemas CINEART, CINE-PAISSANDU and MUSEUM OF MODERN ART, and that they are also considering screening them at 'Casa Grande'.

The inability to characterise the guests of the Ball with precision ("the same type of audience") justifies, as much as the revealing excitement of the agent, the quantity of photographs taken, and also the making of a specific dossier to gather information about the Fe.BeA.Pa., which, like so many other acronyms of the left, became one more suspicious movement that needed to be watched by the police of Rio de Janeiro.

\section{7 - A "confusionist" in Central do Brasil}

If the photographer working for the political police occasionally becomes a "tourist" or a "reveller", who participates, to a greater or lesser degree, in the activities that he is watching, he is more frequently the furtive glance, the "spy". He acts discreetly, but not to the point where he does not inscribe in the image his own condition and circumstance. His photographs are in general produced on the street, usually from

\footnotetext{
8 By the time of this ball, Marshall Costa e Silva had already been chosen as the next military president of Brazil. His term
} started on March 15, 1967. 
within vehicles whose windows help not only to frame the focus of surveillance interest, but also to mark the secret character of its accomplishment. A common feature of the large majority of these "observation" images, as they were called, is the lack of sharpness, the poor focus, as in Photographs 11 to 13, selected from a sequence of six photographs dated March 30, 1977. The target of the DOPS agent, signalled by an arrow in all the images, is Anaxílio Evangelista Barbosa, caught here talking to unidentified persons at Central do Brasil railway station

Despite the extent of the photographic archives of the political police, few people received such acute attention as this obscure Anaxílio. In the file of the Police, there are six entries with his name from the years: 1965, 1967, 1971 and 1977. These records suggest that Anaxílio was considered a "suspect" worthy of surveillance for at least twelve years. A record from the Sector of Security and Information of April 6 1977 mentions six annexed photographs, and details that he is "booked" as "pro-communist", "presented since October 10 1965".?

Making profuse use of police terminology, the report goes on to say, "Anaxílio is supposedly linked to the Lawyer Demisthoclides Baptista, a former railway employee, dismissed under the Constitutional Act for being subversive". It adds "the designated is constantly seen meeting with groups in the hall of the building D. Pedro II (concourse of Central do Brasil railway station) according to the attached copies of photograph" (APERJ: 150,14). There are two "confidential" stamps on this file, and another one with the following warning: "The receiver is responsible for the maintaining of the secrecy of this document (Art. 62 v- Dec. Number 60141767 - Regulation for the safeguarding of secret subjects)". The countless stamps, signatures and dates included in the dossier prove that the photographs and data about Anaxílio circulated through several departments.

In order to understand this interest in Anaxílio on the part of the police, we must go back to 1965, the year of his "presentation". His name shows up for the first time in an extensive report about railway workers that used to be part of the by then illegal Brazilian Communist party. Composed of over 300 names, this report lists "militants", "affiliates", "contributors" and "sympathisers" in alphabetical order. It is only in relation to Anaxílio that any further detailed information is given. What follows is a translation of the record, preserving its peculiar syntax:

Machinist, currently reclassified as Master, resides at 41 Orestes Street, aside from many other residences. He works on the railway, always as a machinist, a duty that he did not perform for very long, always involved in politics, he has travelled across Europe; as a representative of railway workers, he keeps many photographs of leaders of the PC [the Communist Party]. Several autographs of these leaders, according to what he showed one of us. He has been booked by the São Paulo Police, and his file says that he is an opportunist, mixed in politics, always with propaganda for the PTB [Brazilian Labour Party], but underneath, his cloak is red; he ran for city councillor and the patron of his campaign was the domestic workers' union, a union that is under observation. He has several residences in that state, for example 463 Almeida Lima Street, 665 Guarulhos Avenue, and many others, 2.703 Bruner Street. Is known to the police by the nickname "Vavá", in Rio has a car from where he makes his propaganda, attacks and at the same time defends authorities, a real "confusionist" (APERJ: 69, 4, 28).

\footnotetext{
9 "Presented", that is, included in the files of the Political Police. The expression (which also means "introduced") was common, since most "suspects" had never been arrested, detained or the subject of any judicial proceedings. The "presentation" might result from links which the suspect maintained with individuals who had been previously "presented", or due to data collected by "infiltrated" agents or informants. In the great majority of cases, the information existing in the file omits (for their own protection, it is imagined) the source of the presentation.
} 
Anaxílio, the confusionist, clearly intrigued the police..$^{10}$ The officer not only describes him as smart and furtive ("underneath, his cloak is red"), but also appeals to expressions that indicate the efficiency of the surveillance and the reasoning capability of its agents. Thus, the railway worker has shown his collection of autographed photographs to "one of us", and tried to run for city councillor with the support of the domestic workers" union, which is "under observation".

A few months later, on March 8 1966, new data was requested by the Section of Antidemocratic Activities (S.A.A.), which should "investigate" the "above mentioned", who "is always at Central do Brasil, where he contacts subversive persons from whom he receives and transmits communications". The investigations, which took place in the ensuing months, were concluded in August 1966. The report, dated from August 17, reads:

This team, through its investigations, has found out that Anaxílio Evangelista Barbosa lives almost exclusively from politics (electoral offices), working for candidates running for state deputy, congressman, senator, etc. Several times, the above mentioned has travelled to other cities with his expenses paid by politicians (...)

Several times, the 'element' [the suspect] has been seen with small groups of people in the vicinity of Central do Brasil, however, the topics discussed could not be verified, for the participants in the discussions move away on the arrival of any stranger (APERJ: 69, $4,31)$.

On receiving this information, the then chief of S.A.A. sent the document to the S.I. (Information Service), for filing, on September 11966.

In 1967, another request for information about Anaxílio was made, but no new investigations were carried out, and the data from his presentation file was merely repeated. It was only ten years later, in 1977, that the railway worker was spied on, for the first time, by a police photographer. In spite of all his "confusionism" and of the prolonged interest in his activities on the part of the police, the railway worker was easily found. Twelve years later, he still frequented the hall of D. Pedro II Station, at Central do Brasil railway station. And he still met with small groups in this public place in order to debate issues whose content can only be surmised. Above all, he was still something of a stranger to the investigators and higher personnel of the police, which rendered necessary his identification with an arrow in each of the photographs.

Without being able to hide in the interior of a car, as was customary on surveillance missions, the photographer had to walk around the hall, keeping a safe distance from his target. The camera was positioned low, probably hidden inside a packet or a briefcase. The care taken in keeping oneself invisible while facing an element known to be both smart and suspicious - he stopped talking every time a stranger approached - is reinforced by the presence, in the image, of a young man wearing a dark shirt and holding a folded newspaper, a few meters from Anaxílio and his group (Photographs 11, 12 and 13). A more or less improvised 'lookout' for the suspect or of one the others in his company, the young man also moved around, paying attention to anyone who approached. It is mainly from the look of this young man that the photographer hid. It was his look that determined the distance, the point of view and the possibility for the photographer-spy to take his pictures.

\footnotetext{
10 While the report refers to the PTB (Brazilian Labor Party), Anaxílio actually ran for city councilor for the PSD (Social Democratic Party). This was in 1958 . He received only 1249 votes, less than $25 \%$ of the necessary minimum to win a seat on the City Council in that particular year.
} 


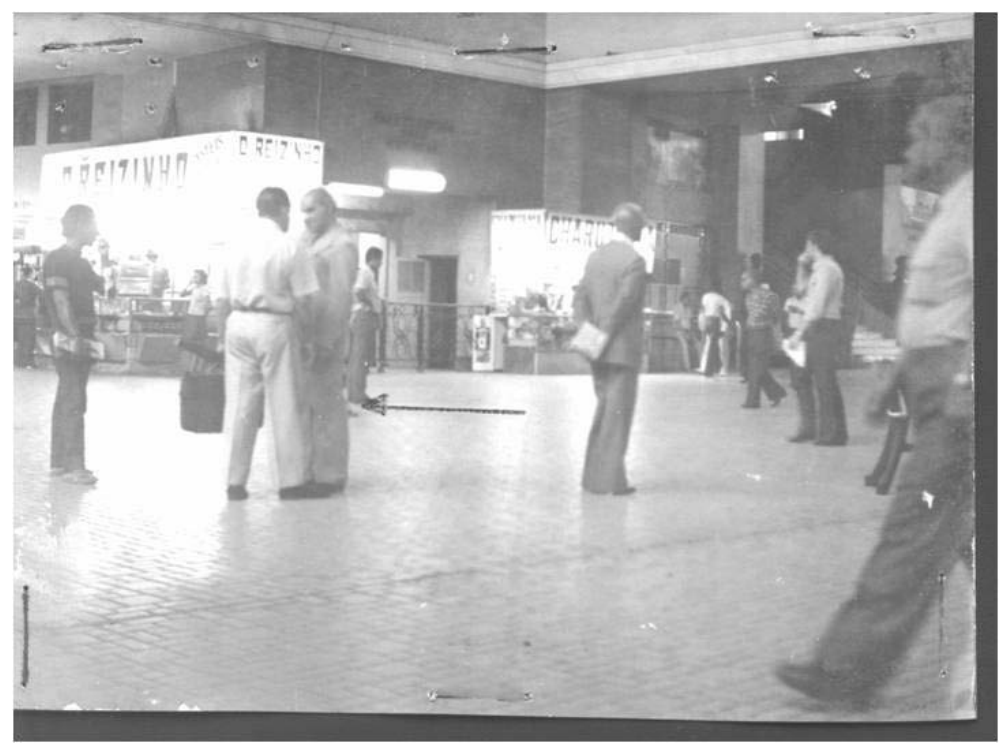

Photograph 11

Surveillance photograph taken in Central do Brasil, 03/30/1977. The man watched is indicated by an arrow. APERJ Photographic Collection.

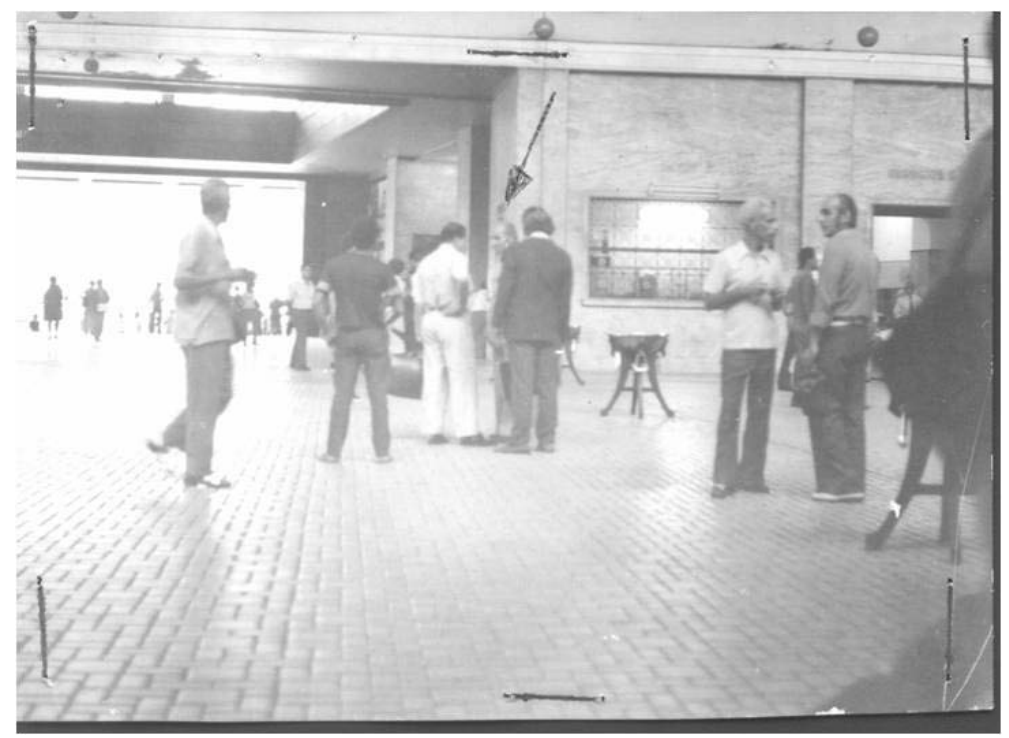

Photograph 12

Surveillance photograph taken in Central do Brasil, 03/30/1977. The police photographer is circulating his targets. APERJ Photographic Collection. 


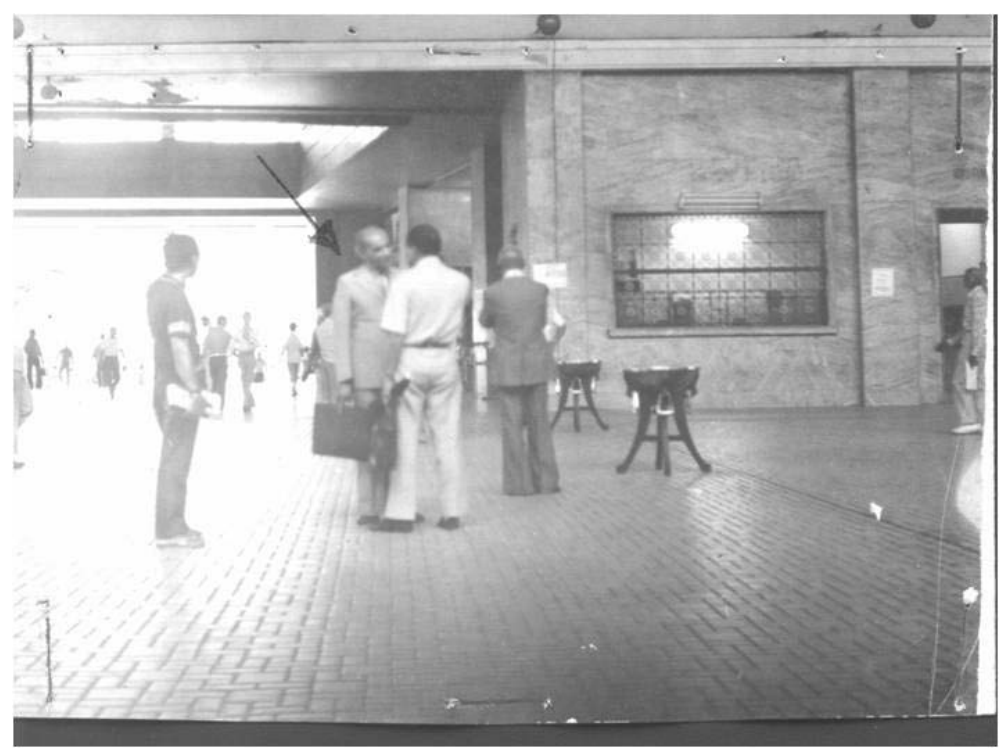

Photograph 13

Surveillance photograph taken in Central do Brasil, 03/30/1977. The man holding the newspaper is protecting the group, watching for the presence of strangers. APERJ Photographic Collection.

This duel of furtive looks that never meet marks here the swan song of the photographic services of the Political Police of Rio de Janeiro. The "opening" of the regime was beginning, the Amnesty was not far away and in a few years DOPS would be closed down all over the country. Despite being circulated through countless sections, these photographs end up revealing nothing of the intentions of Anaxílio the confusionist. Twelve years after his "presentation", what he does or does not do in the hall of the railway station is no longer of any importance. Of the traces left by these images, all that is left is the ballet of surveillance.

\section{Surveillance and subjectivation}

In the beginning of the 1970s, the chiefs of STASI - the powerful police for State Security in East Germany - concluded that photographic techniques should be part of the basic training of every agent. A lieutenant colonel, in an instruction lecture, affirmed:

The camera in the hands of the police is an important weapon in the fight against the enemy and one that, at times, can be employed more frequently and more efficiently than the service weapon we carry constantly and whose handling we practice continuously (Hartewig 2007: 124).

This practice was particularly necessary because, within the STASI, they were creating more and more ways to camouflage their mini-cameras: "pieces of clothing, bags, carrier bags, wallets, motorcycle helmets". "Target practice!" - the instructors recommended constantly on the back of the images, without realizing what that would imply for the agent whose camera was hidden in a bra (or, on the contrary, amusing themselves with it). For the standards of the STASI, the "target" is the ultimate proof of the value of a surveillance photograph. To "target", however, is far from exhausting the photographers' gestures associated with the surveillance images that we found in the DOPS archives. In other words, it is not in the mere indication that the indexicality of the surveillance photographs analyzed here resides.

Thus, our watcher is first a tourist, then a reveller and, finally, a spy. The contrast between these three characters, however, is a surface effect. Mimetic forces have a vigorous role on the configuration of these images; while facing what is disguised, the photographer hides; while facing what is ostensive, he shows 
himself. Was not all the wisdom of surveillance always knowing how to combine these two poles in a continuous process of exhibition and hiding? Each photograph is an opportunity for the photographerwatcher to constitute himself as the one who hides and shows himself, leaving in the image the traces of his choice, the indexes of his enunciation. These marks, if they do not come from an authorship in the strict sense, come from a Bakhtinian authoration, from a dialogism where the watchers and the watched tangle each other reciprocally and alternatively (Bakhtin 1992).

The images taken of the furtive conversation of a railway worker in Central do Brasil in 1977 show us the surveillance topus in its unsophisticated state, fulfilling itself in the game of reciprocal elusiveness. The picturesque photos of the Soviet oceanographers, taken in 1959, where the photographer resorts to irony and parody to comment on the facts he observes, stand in acute opposition to the images from 1977. These two photographic sets, in the eighteen years that separate them, also highlight the process through which the Brazilian political police became, due to its tacit subordination to the agencies of military intelligence, more police than political.

Nowadays, the relationships between surveillance and subjectivation are usually thought of within the scope of a post-disciplinary scene. Their fundamental premise is that the "act of seeing" supposedly became a pure statement without an enunciation: an exaggerated form of panopticism based on achiropoetic apparatuses. We would be, therefore, very far from the time when one could say that it is "thanks" to the whip that "the subjectivity of the watcher leaves the trace in the subjectivity of the slave and vice-versa" (Portelli 1996), from that dialectic instance where the captive tries to decipher in the regard of the slave master the taste or the distaste for the whip. On this long journey that leads us from the dialectic of classic surveillance (slave masters/slaves) to the dialogic of modern surveillance (watchers/watched watching each other reciprocally) and to the state of exception that became a rule (Agamben 2005b) of contemporary surveillance (with the generalisation of watching machines), the watchful eye was progressively losing its gestures. The statement "Smile, you're being filmed" can now be fully understood. This joke, in reality, is an epitaph. A melancholic gesture from the one who leaves, and who could have written in its place: "Here lies the last watcher."

Facing his grave, we can better understand where the parentheses opened by the smile of the infamous have taken us: first, to collect a small inventory of gestures through which the watchers mark their condition in the image: infiltration and irony in the series about the Soviet scientists; exhibitionism and conceit in the series about the festive left; dissimulation and fear in the series about the railway confusionists. And second, to suggest that these gestures from which the photographs will become impregnated with meaning, indict not only those they indicate (that is, the watched), but a field of tensions where the photographs of the political police find their origin. In that sense, it is proposed that a certain exotopical dialogism (that is, reciprocally constituted by looks that are exterior to one another, but interior to a surveillance situation) is the dominant aesthetic characteristic in the formal aspects of these photographs. We have already perceived, not without astonishment, that surveillance photographs, such as those which were taken by the political police, are radically different from snapshots, even those taken by hidden cameras. They are rather, as Roland Barthes would have been pleased to conclude, a "kind of pose".

By turning his epitaph into a joke, the last watcher has left us, however, a clue for an alternative line of destiny. But such a fragile one, that only now are we able to find it again in the faces of these men and women whose lives were "put in play" in the precise fraction of a second of their capture by the apparatus of identification. "How should we understand" - asks Agamben - "the modality of this singular presence, by which a life appears to us only through what silences it and twists it into a grimace?" (2007b: 59) In what other way than through the subversive infiltration of a way-of-life in the interstices of physiognomy? This place, proposes Agamben, belongs to the "author". The author "marks the point at which a life is offered up and played out in the work." It results from a gesture, from "the encounter and from the hand- 
to-hand confrontation with the apparatuses in which it has been put - and has put itself - into play" (6163)

Now, when we go back to the booking photographs with which we began this article, we realise that, contrary to what was suggested previously, the watcher-photographer is not the ultimate receiver of the small excesses of expression of the watched. In this signalectic surface from where all theatricality should have been banned, it was all about the image, from the beginning. It was about sparkling, in the most hidden and feared apparatus - there, where surveillance itself had become unnecessary -, an author and a work. It was about shining, in the very brief time that remains to them, the gleam of a self-portrait.

\section{Acknowledgements}

The authors express their appreciation to FAPERJ (Fundação de Amparo à Pesquisa do Estado do Rio de Janeiro) for its support of the research that resulted in the publication of this article.

\section{References}

A Contradita: polícia política e comunismo no Brasil: 1945-1964: entrevistas com Cecil Borer, Hércules Corrêa dos Reis, José de Moraes e Nilson Venâncio. 2000. Rio de Janeiro: Arquivo Público do Estado do Rio de Janeiro.

Agamben, Giorgio. 2005a. “O Que é um dispositivo?”. In: Outra Travessia (Florianópolis), n. 5. Universidade Federal de Santa Catarina.

Agamben, Giorgio. 2005b. State of exception. Chicago: University of Chicago Press.

Agamben, Giorgio. 2007a. The Coming Community. Minneapolis: University of Minnesota Press.

Agamben, Giorgio. 2007b. "O Autor como gesto". In: Profanações. São Paulo: Boitempo.

APERJ, Political Police Archive, Communism Sector Files.

Arquivo Público do Estado do Rio De Janeiro. 1993. DOPS: a lógica da desconfiança. Rio de Janeiro.

Arquivo Público do Estado do Rio De Janeiro. 1994. Os arquivos das polícias políticas: reflexos de nossa história contemporânea. Rio de Janeiro: FAPERJ.

Bakhtin, Mikhail. 1992. Estética da criação verbal. São Paulo: Martins Fontes.

Deleuze, Gilles. 1992. "Post-scriptum sobre as sociedades de controle”. In: Conversações. Rio de Janeiro: Editora 34.

Fico, Carlos. 2001. Como eles agiam. Rio de Janeiro: Record.

Foucault, Michel. 1977. Vigiar e Punir. Petrópolis: Vozes.

Foucualt, Michel. 1988. História da Sexualidade I. Rio de Janeiro: Graal.

Foucault, Michel. 2003. “A Vida dos Homens Infames”. In: Ditos e Escritos IV. Rio de Janeiro: Forense Universitária.

Hartewig, Karin. 2007. "Imagens do inimigo: oposição e dissidência política nas fotografias do Ministério da Segurança de Estado da Republica Democrática da Alemanha”. In: Tempo, Rio de Janeiro, n14.

Lissovsky, Mauricio. 1993. “O Dedo e a Orelha”. In: Acervo (Rio de Janeiro), v. 6. n. 1-2. Arquivo Nacional.

Mendonça, Eliane Rezende Furtado de. 1998. Documentação da Polícia Política do Rio de Janeiro. Revista Estudos Históricos, Rio de Janeiro, vol. 12, n.22.

Motta, Rodrigo Patto Sá. 2002. Em guarda contra o "Perigo Vermelho": o anticomunismo no Brasil (1917 - 1964). São Paulo: Perspectiva: FAPESP.

Portelli, Alessandro. 1996. "A Filosofia e os Fatos: Narração, interpretação e significado nas memórias e nas fontes orais". In: Tempo. Rio de Janeiro, vol. 1, $\mathrm{n}^{\circ}$. 2, p. 59-72.

Reznik, Luís. 1994. istagem resumida dos setores da Polícia Política. Rio de Janeiro: APERJ / PRODERJ.

Virilio, Paul. 1994. A Máquina de Visão. Rio de Janeiro: José Olympio. 